\title{
Surface reaction of Bacillus cereus biomass and its biosorption for lead and copper ions
}

\author{
PAN Jian-hua, LIU Rui-xia, TANG Hong-xiao* \\ State Key Laboratory of Environmental Aquatic Chemistry, Research Center for Eco-Environmental Sciences, \\ Chinese Academy of Sciences, Beijing 100085, China.E-mail: pjh311@yahoo.com.cn
}

Received 30 March 2006; revised 25 April 2006; accepted 29 April 2006

\begin{abstract}
In this study, the surface chemical functional groups of Bacillus cereus biomass were identified by Fourier transform infrared (FTIR) analytical technique. It had been shown that the B. cereus cells mainly contained carboxyl, hydroxyl, phosphate, amino and amide functional groups. The potentiometric titration was conducted to explain the surface acid-base properties of aqueous $B$. cereus biomass. The computer program FITEQL 4.0 was used to perform the model calculations. The optimization results indicated that three sitesthree $\mathrm{p} K_{\mathrm{a}} \mathrm{s}$ model, which assumed the cell surface to have three distinct types of surface organic functional groups based on the IR analysis results, simulated the experimental results very well. Moreover, batch adsorption experiments were performed to investigate biosorption behavior of $\mathrm{Cu}(\mathrm{II})$ and $\mathrm{Pb}$ (II) ions onto the biomass. Obviously, the adsorption equilibrium data for the two ions were reasonably described by typical Langmuir isotherm.
\end{abstract}

Key words: Bacillus cereus; biosorption; Fourier transform infrared (FTIR); acid-base characteristic; heavy metals

\section{Introduction}

Bacteria are common in many geologic environments where they represent a significant proportion of the overall surface area exposed to fluids containing dissolved solutes. Their cell walls contain a variety of surface organic functional groups, which exhibit a high affinity to bind metals (Beveridge and Murray, 1976, 1980; Fein et al., 1997; Daughney et al., 2002) and other chemical species (Daughney and Fein, 1998a; Fein and Delea, 1999). The ubiquity of bacterial cells in near-surface fluidrock systems and their ability to bind chemicals play a significant role in many geochemical processes. They also help in the subsurface transport of contaminants (Corapcioglu and Kim, 1995), the accumulation of metal deposits (Savvichev et al., 1986), mineralization, and fossilization of microorganisms (Ferris et al., 1988; Konhauser et al., 1993; Fortin et al., 1997; Warren and Ferris, 1998).

Heavy metals are present in nature and industrial wastewater. Due to their mobility in the natural water ecosystem and their toxicity to organisms, the presence of heavy metals in surface and groundwater causes a major inorganic contamination problem that is of worldwide concern (Chang et al., 1996). The behavior, transport, and ultimate fate of heavy metal in natural systems depend largely on the sorption with microorganisms, such as bacteria, fungi, and yeast (Beveridge and Doyle, 1989;

Project supported by the National Natural Science Foundation of China (No. 20537020, 20677073). *Corresponding author.

E-mail: tanghx@rcees.ac.cn.
Poole and Gadd, 1989). It has been reported that different types of biomass were capable of efficiently accumulating heavy metal ions (Volesky and Holan, 1995). One of the most important types of biosorbents is bacteria biomass. The adsorption of heavy metals onto bacterial cell walls has received considerable attention in recent experimental and modeling studies, including several studies utilizing site-specific surface complexation approaches (Fein and Delea, 1997; Daughney and Fein, 1998b; Daughney et al., 1998, 2002). As an essential part of describing these biosorption phenomena, the investigations on the cell surface appearance, chemical functional groups identification, and acid-base characteristics of the biomass are necessary for predicating metal biosorption behavior in the water system and modifying metal biosorption property.

Therefore, acid-base titration and metal adsorption experiments were carried out to explore the microbial surface site reactions and thermodynamic properties of the organic functional groups, which are displayed on Bacillus cereus cell wall surfaces. An attempt was also made to analyze the functional groups of bacterial surface using Fourier transform infrared (FTIR); the knowledge of these functional groups could be employed to explain the more probable mechanism of metal immobilization on the cell wall.

\section{Materials and methods}

\subsection{Metal solutions}

Metal salts used for the batch adsorption experiment were of analytical reagent grade: $\mathrm{Pb}\left(\mathrm{NO}_{3}\right)_{2}, \mathrm{Cu}\left(\mathrm{NO}_{3}\right)_{2}$. 
Separate stock metal solutions were made at a level of 1000 $\mathrm{mg} / \mathrm{L}$ by dissolving an appropriate amount of individual metal in water with nitric acid. Working standards with a range of metal concentrations were prepared by diluting the stock solution. Medium $\mathrm{pH}$ values were adjusted using guaranteed reagent grade $\mathrm{NaOH}$ and $\mathrm{HNO}_{3}$ solution. Distilled deionized (DDI) water was used in all the experiments.

\subsection{Bacterial growth and preparation}

B. cereus was isolated from natural waters near Guanting Reservoir, Hebei Province, China. Bacteria cells were cultured in $600 \mathrm{ml}$ of nutrient broth for $72 \mathrm{~h}$ with growth condition: $\mathrm{pH} 7.2-7.5$, temperature $30^{\circ} \mathrm{C}$, and stirring speed of $160 \mathrm{r} / \mathrm{min}$. The bacteria were then harvested from the growth media by centrifugation at $7000 \mathrm{r} / \mathrm{min}$ for 30 min, rinsed 4-6 times in DDI water. The biomass was freeze-dried at $-50^{\circ} \mathrm{C}$ and the pressure was reduced for 24 $\mathrm{h}$ with a freeze dryer (ALPHA 1-2 LD, Christ, Germany). The species of $B$. cereus is a gram-positive bacterium.

\subsection{Biosorption isotherm}

The batch biosorption experiments were carried out to determine the equilibrium distribution of lead and copper between the aqueous phase and biomass. In the experiments, an aqueous solution containing a known concentration $(5-100 \mathrm{mg} / \mathrm{L})$ of either $\mathrm{Pb}(\mathrm{II})$ or $\mathrm{Cu}$ (II) in a $0.01-\mathrm{mol} / \mathrm{L} \mathrm{NaNO}_{3}$ electrolyte was placed in contact with a biomass concentration of $1 \mathrm{~g} / \mathrm{L} \mathrm{B}$. cereus cells, and the desired $\mathrm{pH}$ value was adjusted using a small volume of 0.1 $\mathrm{mol} / \mathrm{L} \mathrm{HNO}_{3}$ or $0.1 \mathrm{~mol} / \mathrm{L} \mathrm{NaOH}(\mathrm{pH}=5.5)$. The mixture was then agitated on a shaker at $25^{\circ} \mathrm{C}$ for $24 \mathrm{~h}$, which was more than ample time for adsorption equilibrium, based on the results of the previous kinetics experiments. After $24 \mathrm{~h}$ of equilibration, the bacterial suspensions were separated by centrifugation and the supernatant was analyzed for dissolved metal content via flame atomic absorption spectrophotometer (AAS, Hitachi, Z-6100).

\subsection{FTIR analysis of biomass}

To complete the study of functional groups, an IR analysis was performed with a FTIR spectrometer (Thermo Nicolet Nexus 670 FTIR, GMI, USA). $5 \mathrm{mg}$ of dried bacteria biomass was mixed and ground with $150 \mathrm{mg}$ of $\mathrm{KBr}$ (Spectral) in an agate mortar. The translucent disks were prepared by pressing the ground material with the aid of 8 - $t$ pressure bench press. The tablet was immediately analyzed using a spectrophotometer in the range of 4000$400 \mathrm{~cm}^{-1}$ with a resolution of $4 \mathrm{~cm}^{-1}$. The influence of atmospheric water and $\mathrm{CO}_{2}$ were always subtracted.

\subsection{Potentiometric titration of biomass}

A certain amount of $3 \mathrm{~g} / \mathrm{L}$ biomass stock suspension was added to a $100-\mathrm{ml}$ flask, and $1 \mathrm{~mol} / \mathrm{L} \mathrm{NaNO}_{3}$ was used to stabilize the system at a fixed ionic strength. A total batch volume of $90 \mathrm{ml}$ was made up by adding DDI water (Table 3 for experimental run conditions). The suspension was stirred magnetically and continually bubbled with $\mathrm{N}_{2}$ for $60 \mathrm{~min}$ in order to purge $\mathrm{CO}_{2}$ until the $\mathrm{pH}$ value was constant. Afterward, $0.05005 \mathrm{~mol} / \mathrm{L} \mathrm{HNO}_{3}$ was added using a Metrohm 716 DMS autotitrator and the equilibrium $\mathrm{pH}$ value of the suspension became lower than 3 so that the biomass was converted to hydrogen form. The back titration process was conducted with 0.04898 $\mathrm{mol} / \mathrm{L} \mathrm{NaOH}$ until the $\mathrm{pH}$ of the suspension was raised to about 11. During the titration procedure, $\mathrm{N}_{2}$ was bubbled throughout the experiment process and the mixture was stirred magnetically, the temperature being held constant at $25 \pm 0.5^{\circ} \mathrm{C}$. The equilibrium criterion for each addition of the titrant was that the drift of the measured potential should be below $1 \mathrm{mV} / \mathrm{min}$ or equilibrium $90 \mathrm{~s}$. For each experiment, the corresponding blank titration was carried out on a solution of the background electrolyte $\left(\mathrm{NaNO}_{3}\right.$ solution) with the same procedure as the sample except for the presence of the biomass phase.

\section{Results and discussion}

\subsection{Biosorption isotherm}

The results of the $\mathrm{Pb}$ (II) and $\mathrm{Cu}$ (II) adsorption experiments are shown in Fig.1. The analysis of these isotherm data is important to develop an equation, which accurately represented the results and for designing purposes. To fit the sorption data, the Freundlich and Langmuir isotherm models (Öztürk et al., 2004) were applied to this study.

The linearized Freundlich isotherm model is described by the following equation:

$\lg q=\lg k+\frac{1}{n} \lg C_{\mathrm{e}}$

Where, $C_{\mathrm{e}}$ is the equilibrium concentration of heavy metal in the solution $(\mathrm{mol} / \mathrm{L}), q$ is the adsorption capacity at equilibrium $(\mathrm{mg} / \mathrm{g}), n$ is the Freundlich constant related to the energy of adsorption and $k$ is a constant. The values of $k$ and $1 / n$ are evaluated from the intercept and the slope, respectively, of the linear plot of $\lg q$ versus $\lg C_{\mathrm{e}}$ based on experimental data.

The linearized Langmuir isotherm model represented by the equation:

$$
\frac{1}{q}=\frac{1}{b Q_{\max }} \times \frac{1}{C_{\mathrm{e}}}+\frac{1}{Q_{\max }}
$$

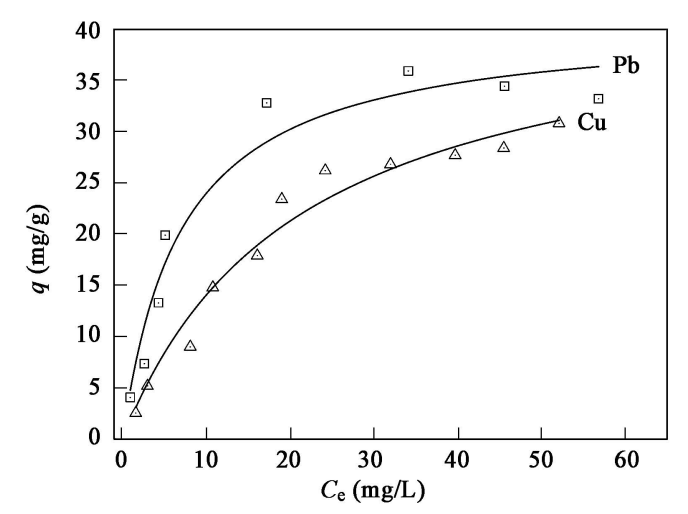

Fig. 1 Isotherms for the equilibrium binding of $\mathrm{Pb}$ (II) and $\mathrm{Cu}$ (II) on $B$. cereus biomass (initial pH 5.5). 

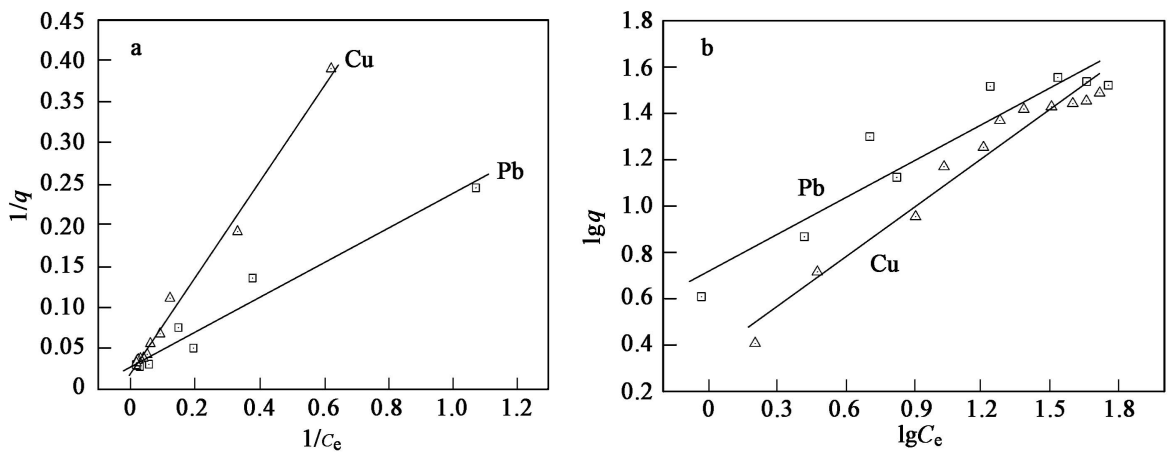

Fig. $2 \mathrm{~Pb}$ (II) and $\mathrm{Cu}$ (II) sorption isotherms on B. cereus biomass according to linearized Langmuir model (a) and Freundlich model (b).

Where, $b$ is the Langmuir parameter (affinity constant of metal-active site species) $(\mathrm{L} / \mathrm{mol})$ and $Q_{\max }$ is the maximum adsorption capacity $(\mathrm{mg} / \mathrm{g})$. These constants are evaluated from the slope and the intercept of the linear plot of $1 / q$ versus $1 / C_{\mathrm{e}}$ based on experimental data.

Adsorption constants, metal-binding constant, and correlation coefficients for the metals, which were calculated from Langmuir, Freundlich isotherms are shown in Table 1. The fitted results indicate the Langmuir isotherm can provide the better description of the adsorption process. The linearized adsorption data with respect to both metals are shown in Figs.2a and 2b.

\subsection{Fourier transform infrared spectroscopy}

In order to understand better the nature of the functional groups responsible for the biosorption, FT-IR analysis of the biomass $B$. cereus was carried out. The spectrum of the biomass is shown in Fig.3 and the IR adsorption bands with corresponding possible groups are shown in Table 2. The spectrum (Fig.3) exhibits a broad absorption band between 3500 and $3200 \mathrm{~cm}^{-1}$ due to bonded $-\mathrm{OH}$ stretching vibration, and in this range, stretching vibration of $-\mathrm{NH}$ groups located at $3306.48 \mathrm{~cm}^{-1}$ can be observed. The peak at $2930.84 \mathrm{~cm}^{-1}$ is the indicator of alkyl chains $-\mathrm{CH}$ stretching vibration. The $\mathrm{C}=\mathrm{O}$ of the carboxylic groups or esters groups stretching vibration, appears at $1728.68 \mathrm{~cm}^{-1}$. The typical amide $\mathrm{I}$ band, $\mathrm{C}=\mathrm{O}$ stretching vibration, appears strongly at $1655.19 \mathrm{~cm}^{-1}$. The peak at $1544.20 \mathrm{~cm}^{-1}$, known as amide II, is contributed to a motion combining both the $-\mathrm{NH}$ bending and the $-\mathrm{CN}$

Table 1 Adsorption isotherm parameters for $\mathrm{Pb}$ (II) and $\mathrm{Cu}$ (II) ions on B. cereus

\begin{tabular}{lccccccc}
\hline Metal ion & \multicolumn{3}{c}{ Langmuir isotherm } & & \multicolumn{3}{c}{ Freundlich isotherm } \\
\cline { 2 - 4 } \cline { 6 - 8 } & $Q_{\max }$ & $b$ & $R^{2}$ & & $n$ & $k$ & $R^{2}$ \\
\hline Lead (II) & 36.71 & 0.129 & 0.962 & & 1.895 & 5.24 & 0.891 \\
Copper (II) & 50.32 & 0.034 & 0.991 & & 1.596 & 2.70 & 0.908 \\
\hline
\end{tabular}

stretching vibration of the group $-\mathrm{C}(=\mathrm{O})-\mathrm{NH}-$ in its transform, and this peak appears as a shoulder with a moderate to strong intensity on $\mathrm{C}=\mathrm{O}$ stretching vibration absorption. Sometimes, the $\mathrm{C}(=\mathrm{O})-\mathrm{O}^{-}$anti-symmetric stretching vibration in carboxylate so-called $v_{\mathrm{C}=\mathrm{O}}$ (I) appears around $1544.20 \mathrm{~cm}^{-1}$ wavenumbers. The small absorbance peak at $1453.60 \mathrm{~cm}^{-1}$ are due to $-\mathrm{CH}_{2}$ scissoring or $-\mathrm{CH}_{3}$ antisymmetrical bending vibration. The other typical amide band (amide III) located in $1381.11 \mathrm{~cm}^{-1}$ is identified, and in general, the $\mathrm{C}(=\mathrm{O})-\mathrm{O}^{-}$symmetric stretching vibration in carboxylate is overlapped in the wavenumbers. The $\mathrm{C}(=\mathrm{O})-\mathrm{O}^{-}$stretching vibration coupled to the $-\mathrm{OH}$ inplane deformation, aromatic amines $(-\mathrm{C}-\mathrm{N}-), \mathrm{P}=\mathrm{O}$ and $\mathrm{S}=\mathrm{O}$ stretching vibration all exhibit the moderate band at about $1291.09 \mathrm{~cm}^{-1}$. The peaks at 1184.29 and 1055.95 $\mathrm{cm}^{-1}$ may be attributed to $\mathrm{C}-\mathrm{N}$ stretching vibration of amine groups, $\mathrm{P}-\mathrm{O}-\mathrm{C}$ links of the organic phosphated groups and $\mathrm{P}-\mathrm{O}$ vibration of $\left(\mathrm{C}-\mathrm{PO}_{3}{ }^{2-}\right)$ moiety (Heber et al., 1952; Lin-Vien et al., 1991; Fourest and Volesky, 1996; Romero-Gonzalez et al., 2001; Socrates, 2001; Selatnia et al., 2004; Naja et al., 2005). Therefore, infrared spectra of B. cereus biomass showed the presence of amine $\mathrm{R}-\mathrm{NH}_{2}$ (amino acids, proteins, glycoproteins, etc.), carboxylic acid (fatty acids, lipopolysaccharides, etc.), hydroxyls, and

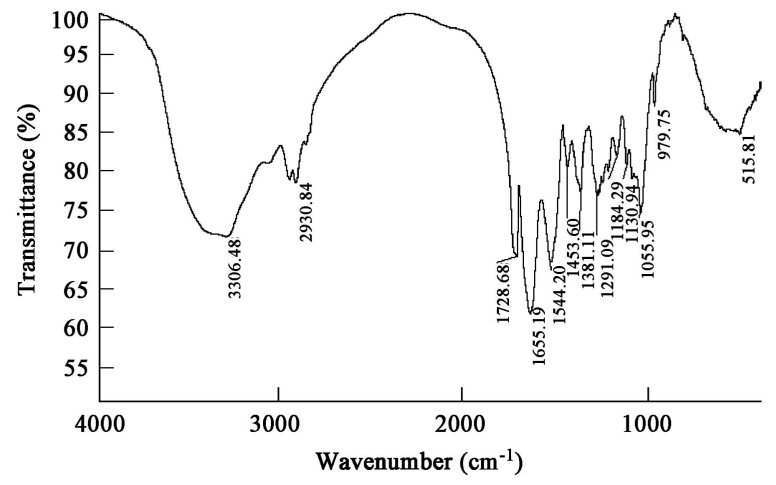

Fig. 3 IR spectrum of B. cereus biomass.

Table 2 IR adsorption bands and corresponding possible groups

\begin{tabular}{llll}
\hline Frequency $\left(\mathrm{cm}^{-1}\right)$ & Functional group & Frequency $\left(\mathrm{cm}^{-1}\right)$ & Functional group \\
\hline 3306.48 & $-\mathrm{OH},-\mathrm{NH}$ & 1453.60 & $-\mathrm{CH}$ \\
2930.84 & $-\mathrm{CH}$ & 1381.11 & $\mathrm{COO}-\mathrm{C}-\mathrm{N}$ \\
1728.68 & $\mathrm{COO}-\mathrm{C}=\mathrm{O}$ & 1291.09 & $-\mathrm{C}-\mathrm{N}-, \mathrm{P}=\mathrm{O}, \mathrm{S}=\mathrm{O}, \mathrm{COO}-$ \\
1655.19 & $\mathrm{C}=\mathrm{O}$ & 1184.29 & $\mathrm{C}-\mathrm{N}, \mathrm{P}-\mathrm{O}-\mathrm{C}$ \\
1544.20 & $\mathrm{COO},-\mathrm{C}(=\mathrm{O})-\mathrm{NH}-, \mathrm{C}=\mathrm{O}$ & 1055.95 & $\mathrm{P}-\mathrm{O}$ \\
\hline
\end{tabular}


phosphates.

\subsection{Determination of total surface site concentration}

In certain previous studies (Stadler and Schindler, 1993; Chorover and Sposito, 1995; Ludwig and Schindler, 1995; Du et al., 1997; Liu et al., 1999), in-situ Gran plots were utilized to determine the standard electrode potential and the volume of titrant added at the equivalence point for the potentiometric titration of suspension systems. In this study, the Gran plots for $B$. cereus biomass suspension system, as shown in Fig.4, were adopted to ascertain the specific volume of the titrant added at the equivalence point $\left(V_{\mathrm{e}}\right)$, furthermore, to calibrate zero titration point and to calculate the total surface site concentration. For the hydroxide back titration, the Gran plots are obtained by plotting Gran function $(G)$ versus the volume of added sodium hydroxide solution $\left(V_{\mathrm{b}}\right)$, and Gran functions (Gran, 1952) are expressed as:

Acidic side: $G=\left(V_{0}+V_{\mathrm{at}}+V_{\mathrm{b}}\right) \times 10^{E / 59.157}$

Alkaline side: $G=\left(V_{0}+V_{\mathrm{at}}+V_{\mathrm{b}}\right) \times 10^{-E / 59.157}$

where, $V_{0}$ is the initial volume of suspension $(\mathrm{ml}), V_{\text {at }}$ is the total volume of $\mathrm{HNO}_{3}$ added in the acid titration $(\mathrm{ml})$, and $E$ is the potential of glass electrode $(\mathrm{mV})$.

On the basis of the above-mentioned Gran plots, the biomass suspension system of the hydroxide back titration procedure, the added $\mathrm{OH}^{-}$successively participates in the following processes: acid-base neutralization with excess $\mathrm{H}^{+}$in solution (before $V_{\mathrm{e} 1}$ ), binding to the various active sites on the biomass interface (between $V_{\mathrm{e} 1}$ and $V_{\mathrm{e} 2}$ ), and adjustment of the $\mathrm{pH}$ value of the suspension system (after $V_{\mathrm{e} 2}$ ). The specific volumes, $V_{\mathrm{e} 1}$ and $V_{\mathrm{e} 2}$, obtained from results of linear regression analysis of Gran plots, corresponded to the equivalent points. Furthermore, $V_{\mathrm{e} 1}$ was considered as the zero titration point (ZTP) of the suspension system because of only acid-base neutralization occurring in solution phase before the point. For each titration point, the total concentration of consumed protons (TOTH) was calculated by the following equation:

$$
\text { TOTH }=-\left(V_{\mathrm{b}}-V_{\mathrm{e} 1}\right) \times C_{\mathrm{b}} /\left(V_{0}+V_{\mathrm{at}}+V_{\mathrm{b}}\right)
$$

where, $C_{\mathrm{b}}$ is the concentration of $\mathrm{NaOH}(\mathrm{mol} / \mathrm{L})$. The hydroxide titration data after the calibration of ZTP were used in the FITEQL 4.0 program to calculate the surface acidic constants.

According to the Gran plot, the total surface site concentration $\left(H_{\mathrm{s}}, \mathrm{mol} / \mathrm{L}\right)$ could be calculated from the two equivalence points $V_{\mathrm{e} 1}$ and $V_{\mathrm{e} 2}$ using the following equation:

$$
H_{\mathrm{s}}=\left(C_{\mathrm{b}} \times\left(V_{\mathrm{e} 2}-V_{\mathrm{e} 1}\right)_{\text {sample }}-\left(C_{\mathrm{b}} \times\left(V_{\mathrm{e} 2}-V_{\mathrm{e} 1}\right)_{\text {blank }}\right) / V_{0}\right.
$$

All the results are shown in Table 3.

\subsection{Biomass surface acid-base reaction models}

IR analysis of biomass has proven that the B. cereus cell exhibits active carboxyl, hydroxyl, phosphate, and amino or amide functional groups. The acid-base behavior of this bacterium is due to the reaction of functional groups on the cell wall with the change in $\mathrm{pH}$ value. In simulating the surface reaction of $B$. cereus biomass, two surface protonation models are proposed to evaluate the model that best describes the experimental data of systems with different biomass concentrations and ionic strengths. More details concerning model description are shown in Table 3 and Fig.5.
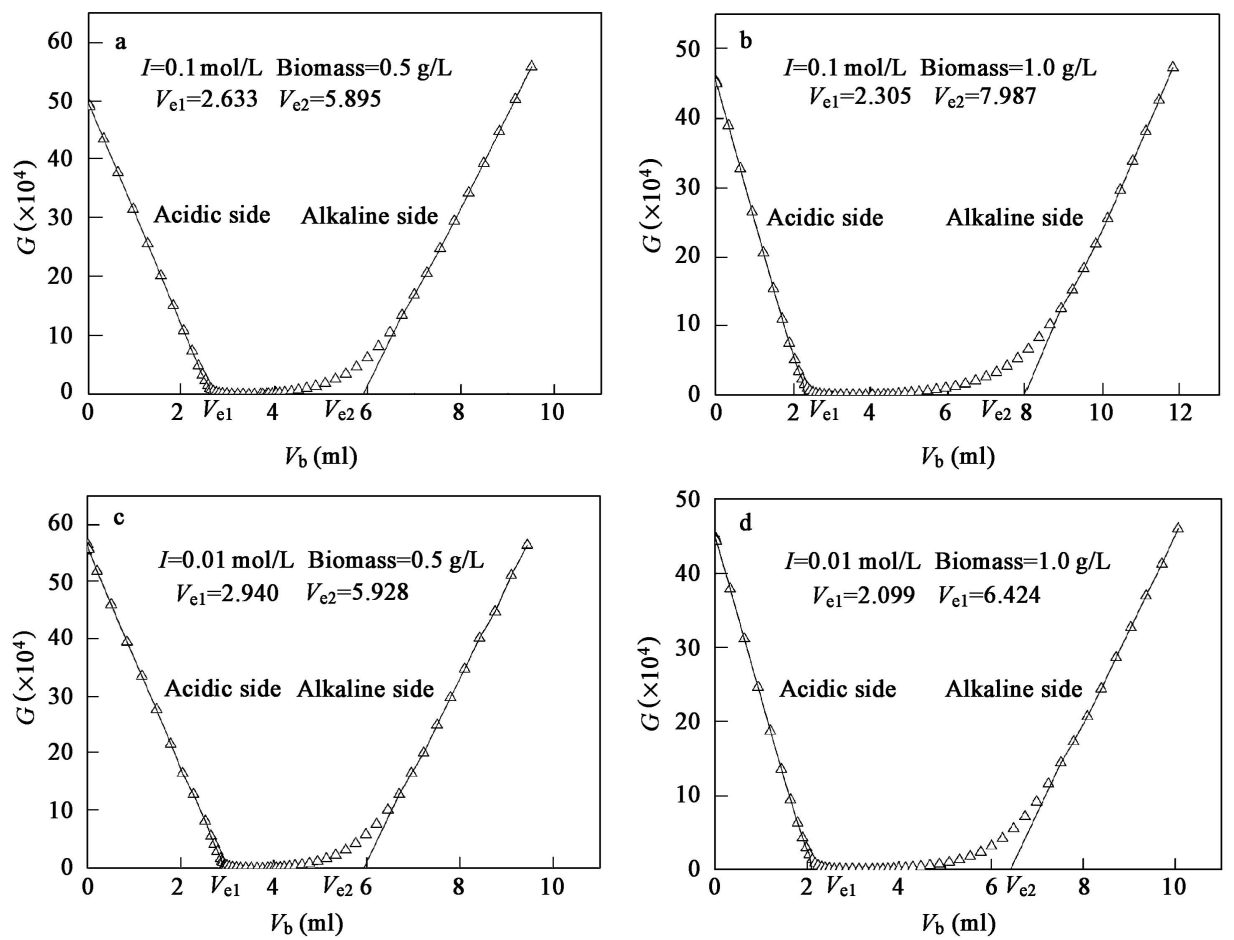

Fig. 4 Gran plots for different titration system. (a) $0.5 \mathrm{~g}$ bacteria/L in $0.1 \mathrm{~mol} / \mathrm{L} \mathrm{NaNO}_{3}$; (b) $1 \mathrm{~g}$ bacteria/ $/ \mathrm{L}$ in $0.1 \mathrm{~mol} / \mathrm{L} \mathrm{NaNO}$; (c) $0.5 \mathrm{~g}$ bacteria/L in $0.01 \mathrm{~mol} / \mathrm{L} \mathrm{NaNO}_{3}$; (d) $1 \mathrm{~g}$ bacteria/L in $0.01 \mathrm{~mol} / \mathrm{L} \mathrm{NaNO}_{3}$. 
$\square$ Data point $\triangle$ One site-two $\mathrm{p} K_{\mathrm{a}} \mathrm{s}$ model (I) $\odot$ Three sites-three $\mathrm{p} K_{\mathrm{a}} \mathrm{s}$ model (II)
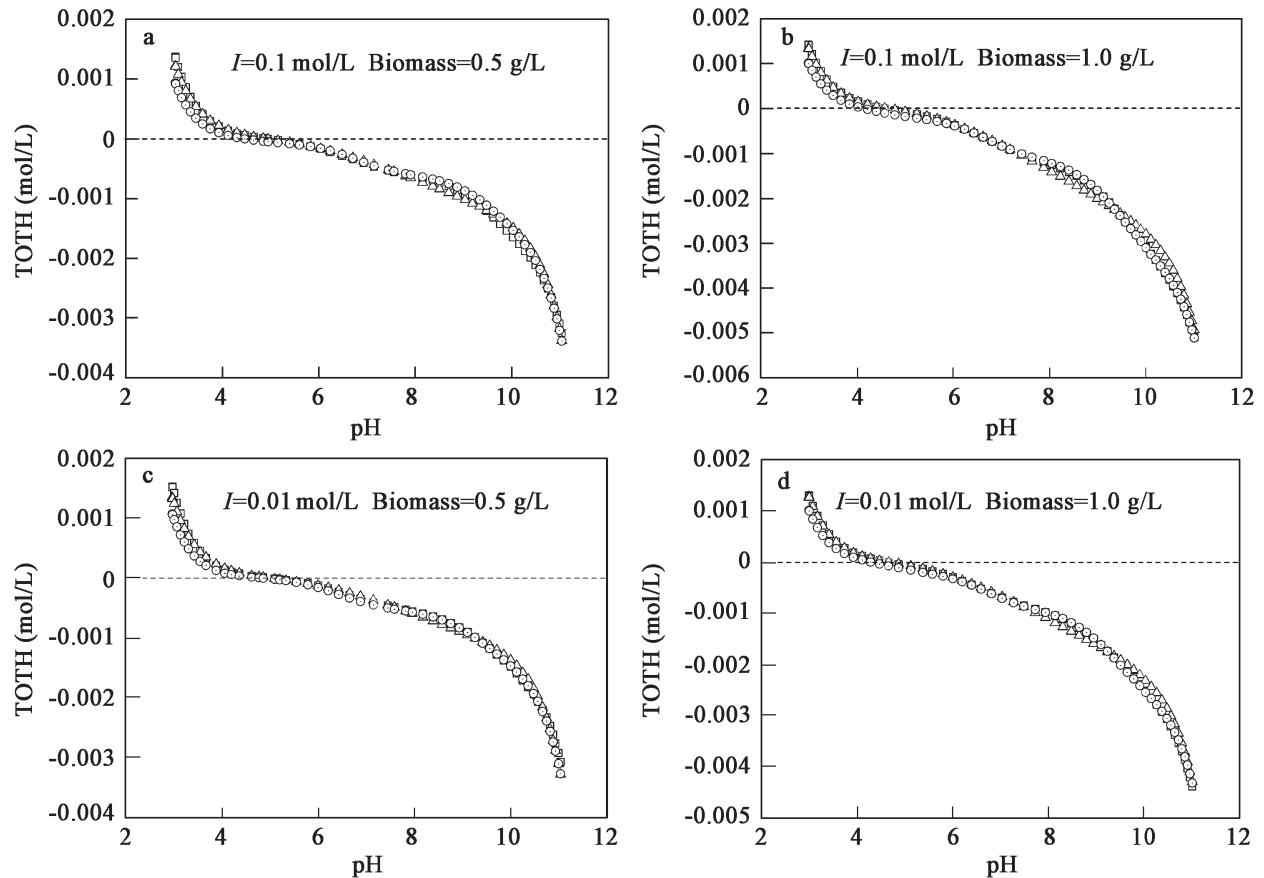

Fig. 5 Model curves of potentiometric titration for the biomass and corresponding experimental data. (a) $0.5 \mathrm{~g} \mathrm{bacteria/} / \mathrm{L}$ in $0.1 \mathrm{~mol} / \mathrm{L} \mathrm{NaNO} 3$; (b) $1 \mathrm{~g}$ bacteria/L in $0.1 \mathrm{~mol} / \mathrm{L} \mathrm{NaNO}_{3}$ and (c) $0.5 \mathrm{~g}$ bacteria/L in $0.01 \mathrm{~mol} / \mathrm{L} \mathrm{NaNO}_{3}$, (d) $1 \mathrm{~g}$ bacteria/L in $0.01 \mathrm{~mol} / \mathrm{L} \mathrm{NaNO}_{3}$.

Table 3 Surface characteristic parameters of $\boldsymbol{B}$. cereus biomass for various systems

\begin{tabular}{|c|c|c|c|c|c|c|c|c|c|}
\hline \multirow[t]{2}{*}{ System } & \multirow[t]{2}{*}{$H_{\mathrm{s}} \times 10^{-4}(\mathrm{~mol} / \mathrm{L})$} & \multicolumn{3}{|c|}{ One site-two $\mathrm{p} K_{\mathrm{a}} \mathrm{s}$ model } & \multirow[t]{2}{*}{ (I) } & \multicolumn{4}{|c|}{ Three sites-three $K_{\mathrm{a}} \mathrm{s}$ model } \\
\hline & & $\mathrm{p} K_{\mathrm{a} 1}$ & $\mathrm{p} K_{\mathrm{a} 2}$ & $V_{Y}$ & & $\mathrm{p} K_{\mathrm{a} 3}$ & $\mathrm{p} K_{\mathrm{a} 4}$ & $\mathrm{p} K_{\mathrm{a} 5}$ & $V_{Y}$ \\
\hline $0.5 \mathrm{~g} / \mathrm{L}$ biomass in $0.1 \mathrm{~mol} / \mathrm{L} \mathrm{NaNO}_{3}$ & 17.59 & 2.73 & 6.89 & 28.05 & & 6.31 & 7.39 & 9.48 & 9.89 \\
\hline $1 \mathrm{~g} / \mathrm{L}$ biomass in $0.1 \mathrm{~mol} / \mathrm{L} \mathrm{NaNO}_{3}$ & 36.89 & 1.26 & 7.67 & 36.47 & & 5.88 & 7.19 & 9.50 & 6.30 \\
\hline $0.5 \mathrm{~g} / \mathrm{L}$ biomass in $0.01 \mathrm{~mol} / \mathrm{L} \mathrm{NaNO}_{3}$ & 15.92 & 2.31 & 7.42 & 26.05 & & 6.48 & 7.98 & 9.45 & 8.78 \\
\hline $1 \mathrm{~g} / \mathrm{L}$ biomass in $0.01 \mathrm{~mol} / \mathrm{L} \mathrm{NaNO}_{3}$ & 27.84 & 1.28 & 7.62 & 23.70 & & 5.90 & 7.21 & 9.39 & 4.58 \\
\hline
\end{tabular}

Surface area is about $119.32 \mathrm{~m}^{2} / \mathrm{g}$ dry biomass, calculated from cell geometry; $V_{Y}$ : model variance.

\subsubsection{One site-two $\mathrm{p} K_{\mathrm{a}} \mathrm{s}$ model}

This surface protonation model is typically used in surface complexation models to study the surface acidic behaviors of solid/water systems (Motta and Miranda, 1989; Wieland and Stumm, 1992). It assumes that the solid interface is homogenous, and that two acidic reactions, one protonation and one deprotonation (as shown in Eqs. (7) and (8)), occur at the amphoteric surface hydroxyl groups $(\equiv \mathrm{ROH})$. The amphoteric properties of the cell surface can be simplified by the following equations:

$$
\begin{aligned}
& \equiv \mathrm{R}-\mathrm{OH}_{2}{ }^{+} \rightleftharpoons \equiv \mathrm{R}-\mathrm{OH}+\mathrm{H}^{+} \quad K_{\mathrm{a} 1} \\
& \equiv \mathrm{R}-\mathrm{OH} \rightleftharpoons \equiv \mathrm{R}-\mathrm{O}^{-}+\mathrm{H}^{+} \quad K_{\mathrm{a} 2}
\end{aligned}
$$

where, $\equiv \mathrm{R}$ is bacterial cell wall, $K_{\mathrm{a} 1}$ and $K_{\mathrm{a} 2}$ are equilibrium constants of Eqs. (7) and (8).

\subsubsection{Three sites-three $\mathrm{p} K_{\mathrm{a}} \mathrm{s}$ model}

This model is established based on the IR analysis results. Bacillus cereus biomass is known to display active carboxyl, hydroxyl, phosphate, amino, and amide functional groups. However, the amine groups are much lesser in number than the other groups. In the model, the active sites of the biomass surface are heterogeneous, and are assumed to contain three distinct types of surface sites with different affinities. The deprotonation reactions of these sites are expressed as:

$$
\begin{array}{ll}
\equiv \mathrm{R}-\mathrm{COOH} \rightleftharpoons \mathrm{R}-\mathrm{COO}^{-}+\mathrm{H}^{+} & K_{\mathrm{a} 3} \\
\equiv \mathrm{R}-\mathrm{POH} \rightleftharpoons \mathrm{R}-\mathrm{PO}^{-}+\mathrm{H}^{+} & K_{\mathrm{a} 4} \\
\equiv \mathrm{R}-\mathrm{OH} \rightleftharpoons \mathrm{R}-\mathrm{O}^{-}+\mathrm{H}^{+} & K_{\mathrm{a} 5}
\end{array}
$$

where, $K_{\mathrm{a} 3}, K_{\mathrm{a} 4}$ and $K_{\mathrm{a} 5}$ are equilibrium constants of Eqs. (9), (10), and (11).

In this study, experiments on systems with two biomass concentrations $(0.5$ and $1 \mathrm{~g} / \mathrm{L})$ of different ionic strengths were conducted. Fig.5 shows that both Model I and Model II fit very well with all experimental data of the studied systems. After the comparison of the two models variance $\left(V_{Y}\right)$ which is an indicator of the goodness of fit, it can be shown that the experimental data are better described by three sites-three $\mathrm{p} K_{\mathrm{a}} \mathrm{s}$ model than other models. For each studied system, the $V_{Y}$ of three sites-three $\mathrm{p} K_{\mathrm{a}} \mathrm{s}$ model varies in the range of 4.58 and 9.89 , indicating an excellent correlation between the model and experimental data. 


\section{Conclusions}

IR spectroscopy result shows that the rod-shaped $B$. cereus cell mainly contains carboxyl, hydroxyl, phosphate, amino, and amide functional groups. Based on the results of potentiometric titration experiments and surface complexation model calculation, it is shown that three sites-three $\mathrm{p} K_{\mathrm{a}} \mathrm{s}$ model, as described by the surface reactions, can reasonably describe the surface acidbase behaviors of $B$. cereus biomass/water system. The Langmuir isotherm can yield the best fit to absorption experimental data for two metals on the biomass.

\section{References}

Beveridge T J, Murray R G E, 1976. Uptake and retention of metals by cell walls of Bacillus subtilis[J]. J Bacteriol, 127: 1502-1518.

Beveridge T J, Murray R G E, 1980. Sites of metal deposition in the cell wall of Bacillus subtilis[J]. J Bacteriol, 141: 876887.

Beveridge T J, Doyle R J, 1989. Metal ions and bacteria[M]. New York: Wiley.

Chang L W, Magos L, Suzuki T, 1996. Toxicology of metals[M]. New York: CRC Press, Inc, Lewis Publishers.

Chorover J, Sposito G, 1995. Surface charge characteristics of kaolinitic tropical soils[J]. Geochim Cosmochim Acta, 59: 875-884.

Corapcioglu M Y, Kim S, 1995. Modeling facilitated contaminant transport by mobile bacteria[J]. Water Resour Res, 31: 2693-2697.

Daughney C J, Fein J B, 1998a. Sorption of 2,4,6-tricholrophenol by Bacillus subtilis[J]. Environ Sci Technol, 32: 749-752.

Daughney C J, Fein J B, 1998b. The effect of ionic strength on the adsorption of $\mathrm{H}^{+}, \mathrm{Cd}^{2+}, \mathrm{Pb}^{2+}$, and $\mathrm{Cu}^{2+}$ by Bacillus subtilis and Bacillus licheniformis: a surface complexation[J]. J Colloid Interface Sci, 198: 53-77.

Daughney C J, Fein J B, Yee N, 1998. A comparison of the thermodynamics of metal adsorption onto two common bacteria[J]. Chemical Geology, 144: 161-176.

Daughney C J, Siciliano S D, Rencz A N et al., 2002. Hg(II) adsorption by bacteria: a surface complexation model and its application to shallow acidic lakes and wetlands in Kejimkujik National Park, Nova Scotia, Canada[J]. Environ Sci Technol, 36: 1546-1553.

Du Q, Sun Z X, Forsling W et al., 1997. Acid-base properties of aqueous illite surfaces[J]. J Colloid Interface Sci, 197: 221-231.

Fein J B, Daughney C J, Yee N et al., 1997. A chemical equilibrium model for metal adsorption onto bacterial surfaces[J]. Geochim Cosmochim Acta, 61: 3319-3328.

Fein J B, Delea D, 1999. Experimental study of the effect of EDTA on Cd adsorption by Bacillus subutilis: a test of the chemical equilibrium approach[J]. Chem Geol, 161: 375383.

Ferris F G, Fyfe W S, Beveridge T J, 1988. Metallic ion binding by Bacillus subtilis: Implications for the fossilization of microorganisms[J]. Geology, 16: 149-152.

Fortin D, Ferris F G, Beveridge T J, 1997. Surface-mediated mineral development by bacteria[M]. In: Geomicrobiology: Interaction between microbes and minerals (Banfield J.F., Nealson K.H., ed.). Reviews in Mineralogy 35. Washington DC: Mineralogical of Society of America, 161-180.

Fourest E, Volesky B, 1996. Contribution of sulfonate groups and alginate to heavy metal biosorption by the dry biomass of Sargassum fluitans[J]. Environ Sci Technol, 30: 227-282.

Gran G, 1952. Determination of the equivalence point in potentionmetric titrations. Part II[J]. Analyst, 77: 661-667.

Heber J R, Stevenson R, Boldman O, 1952. Infrared spectroscopy as a means for identification of bacteria[J]. Scinece. 116: 111-112.

Konhauser K O, Fyfe W S, Ferris F G et al., 1993. Metal sorption and mineral precipitation by bacteria in two Amazonian river systems; Rio Solimoes and Rio Negro, Brazil[J]. Geology, 21: 1103-1106.

Lin-Vien D, Colthup N B, Fateley W G et al., 1991 The handbook of infrared and Raman characteristic frequencies of organic molecules[M]. San Diego: Academic Press.

Liu W X, Sun Z X, Forsling W et al., 1999. A comparative study of surface acid-base characteristics of natural illite from different origins[J]. J Colloid Interface Sci, 219: 48-61.

Ludwig C, Schindler P W, 1995. Surface complexation on $\mathrm{TiO}_{2}$ : I. Adsorption of $\mathrm{H}^{+}$and $\mathrm{Cu}^{2+}$ ions onto $\mathrm{TiO}_{2}$ (anatase)[J]. J Colloid Interface Sci, 169: 284-290.

Motta M M, Miranda C F, 1989. Molybdate adsorption on kaolinite, montmorillonite, and illite: Constant capacitance modeling[J]. Soil Sci Soc Am J, 53: 380-385.

Naja G, Mustin C, Volesky B et al., 2005. A high-resolution titrator: a new approach to studying binding sites of microbial biosorbents[J]. Wat Res, 39: 579-588.

Öztürk A, Artan T, Ayar A, 2004. Biosorption of nickel(II) and copper(II) ions from aqueous solution by Streptomyces coelicolor A3(2)[J]. Colloids and Surface B: Biointerfaces, 34: 105-111.

Poole P K, Gadd G M, 1989. Metal-microbe interaction[M]. Oxford: IRL Press.

Romero-Gonzalez M E, Williams C J, Gardiner P H E, 2001. Study of the mechanisms of cadmium biosorption by dealginated seaweed waste[J]. Environ Sci Technol, 35: 3025-3030.

Savvichev A S, Nikitin D J, Oranskaya M S, 1986. The two phases of colloidal gold accumulation by immobilized microorganisms[J]. Geochem Int, 23: 60-62.

Selatnia A, Boukazoula A, Kechid N et al., 2004. Biosorption of lead (II) from aqueous solution by a bacterial dead Streptomyces rimosus biomass[J]. Biochemical Engineering Journal, 19: 127-135.

Socrates G, 2001. Infrared and Raman characteristic group frequencies: Tables and charts[M]. 3rd ed. England: John Wiley \& Sons Ltd, Baffins Lane, Chichester.

Stadler M, Schindler P W, 1993. Modeling of $\mathrm{H}^{+}$and $\mathrm{Cu}^{2+}$ adsorption on calcium-montmorillonte[J]. Clays and Clay Min, 41: 556-559.

Volesky B, Holan Z R, 1995. Biosorption of heavy metal[J]. Biotechnol Prog, 11: 235-250.

Warren L A, Ferris F G, 1998. Continuum between sorption and precipitation of $\mathrm{Fe}(\mathrm{II})$ on microbial surfaces[J]. Environ Sci Technol, 32: 2331-2337.

Wieland E, Stumm W, 1992. Dissolution kinetics of kaolinite in acidic aqueous solution at $25^{\circ} \mathrm{C}[\mathrm{J}]$. Geochim Cosmochim Acta, 56: 3339-3355. 